Anna R. Burzyńska*

\title{
Czas, który się zatrzymał. Teatr Christopha Marthalera
}

DOI: http://dx.doi.org/10.12775/LC.2018.018

Streszczenie: Artykuł stanowi wprowadzenie do twórczości szwajcarskiego reżysera teatralnego Christopha Marthalera. Opis wybranych spektakli reżysera (Murx den Europäer!, Die Fruchfliege, Riesenbutzbach. Eine Dauerkolonie, Schutz vor der Zukunft) skupia uwagę na jego filozofii rzeczywistości i poglądach politycznych. By uchwycić specyfikę melancholijnego stylu Marthalera i model świata wyłaniający się z jego spektakli, autorka analizuje unikatowy styl aktorstwa w przedstawieniach, koncepcje scenograficzne i rozmaite sposoby wykorzystania muzyki oraz objaśnia konteksty i inspiracje stojące za poszczególnymi projektami.

Słowa kluczowe: Christoph Marthaler, teatr postdramatyczny, muzyka, aktorstwo, pamięć

\section{The time has stopped. The theatre of Christoph Marthaler}

\begin{abstract}
Article is an introduction to the work of Christoph Marthaler, Swiss theatre director. The description of the selected performances (Murx den Europäer!, Die Fruchfliege, Riesenbutzbach. Eine Dauerkolonie, Schutz vor der Zukunft), drawing attention to his philosophical approach of reality and his political ideas. To capture specificity of the Marthaler's melancholy style and the model of the world that emerges in his performances, the author analyses the unique acting style, the concept of set design, and the various ways of using music in his work. At the same time she explains the contexts and inspirations impact various works of Swiss director.
\end{abstract}

Keywords: Christoph Marthaler, postdramatic theatre, music, acting, memory

* Adiunkt w Katedrze Teatru i Dramatu Wydziału Polonistyki Uniwersytetu Jagiellońskiego w Krakowie. Zainteresowania badawcze: najnowszy teatr europejski oraz dramat polski i niemiecki od XIX wieku po współczesność, związki między teatrem i muzyką. E-mail: annaroza@autograf.pl. 
iedy w 1996 roku przedstawienie Murx den Europäer! w reżyserii Christopha Marthalera zostało zaprezentowane na Międzynarodowym Festiwalu Teatralnym „Kontakt” w Toruniu, publiczność (wśród której nie brakowało praktyków - reżyserów, choreografów, aktorów - w późniejszych latach wspominających to formacyjne doświadczenie), krytycy (entuzjastyczne recenzje ukazały się zarówno w specjalistycznych czasopismach, jak i w gazetach codziennych) i jurorzy (którzy nagrodzili inscenizację Grand Prix oraz nagrodą dla najlepszego aktora przyznaną całemu zespołowi spektaklu) mieli świadomość, że oglądają dzieło przełomowe w dziejach europejskiego teatru. Murx... liczył już wówczas trzy lata - premiera odbyła się w berlińskiej Volksbühne w 1993 roku - ale miał jeszcze pozostać w repertuarze przez dekadę (w sumie został zagrany sto siedemdziesiąt osiem razy), zyskując status spektaklu kultowego, którym setki berlińczyków symbolicznie żegnały stary rok (przedstawienie cyklicznie grywano w sylwestra). Z perspektywy czasu widać jeszcze wyraźniej, jak ważna to inscenizacja, diagnozująca stan ducha Europejczyków u progu nowego tysiąclecia, wyprzedzająca trendy inscenizacyjne i aktorskie, będąca esencją i szczytowym osiągnięciem Marthalera.

Wydaje mi się, że można zaryzykować stwierdzenie, że teatr Christopha Marthalera (którego zapewne najdoskonalszą, a bez wątpienia najbardziej znaną realizacją jest spektakl Murx... ) to zjawisko przełomowe i emblematyczne dla nowego teatru, który Hans-Thies Lehmann określił jako postdramatyczny. Postaram się udowodnić, że najpełniej, najbardziej konsekwentnie realizuje się w nim model teatru nielogocentrycznego, zdehierarchizowanego, uwolnionego zarówno od reguł wyznaczonych przez Arystotelesa czy Gustava Freytaga, jak i Bertolta Brechta. Twórczość Marthalera jest wyjątkowym, niemożliwym do przeoczenia kamieniem milowym, przy którym rozchodzą się drogi teatru i dramatu. I mimo że artysta pozostaje jak najdalszy od wypracowywania i ogłaszania „metody” - jego wpływ na kolejne pokolenia twórców (a także kuratorów, badaczy, krytyków i widzów) teatralnych jest nie do przecenienia.

\section{Teatr postdramatyczny}

Pełen tytuł spektaklu brzmi Murx den Europäer! Murx ihn! Murx ihn! Murx ihn! Murx ihn ab. Ein patriotischer Abend von Christoph Marthaler (Zabij Europejczyka! Zabij go! Zabij go! Zabij go! Zabij go! Wieczorek patriotyczny Christopha Marthalera) i został zaczerpnięty $\mathrm{z}$ infantylnej piosenki o Indianach, autorstwa przedwojennego pisarza Paula Scheerbarta. Pomysł na inscenizację narodził się spontanicznie, pod wpływem impulsu, jakim było zetknięcie się zaproszonego do współpracy przez Franka Castorfa szwajcarskiego reżysera z rzeczywistością byłego Berlina Wschodniego. Co prawda w 1992 roku fizyczny mur berliński już nie istniał, jednak mentalny mur między dawnymi Niemcami Zachodnimi i dawnymi Niemcami Wschodnimi był wyższy niż kiedykolwiek. Rozpadające się, bankrutujące stołówki zamykanych zakładów przemysłowych, gdzie pod spłowiałymi transparentami z dumnymi socjalistycznymi hasłami siedzieli pogrążeni w podminowanym agresją stuporze bezrobotni, dla których nie było miejsca w pociągu pędzącym ku nowemu wspa- 
niałemu światu samorealizacji, wolności i bogactwa, zrobiły na Marthalerze wstrząsające wrażenie.

Na apatycznych Ossich rozkaz Różewiczowskiego Chóru Starców przypominającego, że „w teatrze trzeba grać, tu musi się coś dziać” i apelujących: „rusz się, inaczej teatr zgubisz", nie zrobiłby żadnego wrażenia. Także Marthaler nigdy nie przejmował się specjalnie tym naczelnym teatralnym imperatywem. Murx... w wydanym w 1999 roku Teatrze postdramatycznym Hansa-Thiesa Lehmanna (Lehmann 2004) zostanie przywołany jako sztandarowy przykład teatru po dramacie, gdzie ślady utraconej dramatyczności snują się w tle niczym widma, a trzy jedności zostały doprowadzone do absurdu: miejsce akcji to klaustrofobiczne więzienie uniemożliwiające jakiekolwiek działanie, czas się zatrzymał, a akcję sprowadzono do najprostszych, bezcelowych, właściwie odruchowych gestów. Grupa rozbitków ze statku NRD tkwi pogrążona w otępieniu i frustracji na zbutwiałej tratwie dryfującej po kapitalistycznym oceanie: grupka kobiet i mężczyzn, ubranych w spłowiałą, niemodną odzież noszącą ślady dawnej elegancji lub w rozciągnięte dresy, w nietwarzowych okularach $\mathrm{z}$ ubezpieczalni i zdartych butach przesiaduje przy stolikach z płyty pilśniowej w hali będącej połączeniem charakterystycznej architektury starych, zrujnowanych, masowo zamykanych po 1990 roku dworców, terminalu przygotowywanego właśnie do likwidacji lotniska Tempelhof i socjalistycznych stołówek zakładowych. Patrzą tępo na widzów, mieszają apatycznie łyżeczką w szklankach kawę po turecku i czarną herbatę, unikają kontaktu między sobą. Co jakiś czas grana przez akompaniującego im pianistę muzyka budzi w nich wspomnienia, uczucia, emocje. Rozbitkowie wstają z krzeseł, prostują, jednoczą się w chór, nucąc, zawodząc, śpiewając znane wszystkim widzom melodie. Są zamknięci w błędnym kole powtórzeń, z którego nie ma wyjścia.

Polska publiczność oglądająca w 1996 roku po raz pierwszy spektakl Marthalera mogła mieć uczucie déjà vu: podobnie wyglądali i zachowywali się uczestnicy seansu pamięci Tadeusza Kantora Umarła klasa. Podobieństwo jest nieprzypadkowe: w wywiadzie z Klausem Dermutzem Christoph Marthaler przyznał, że oglądał to przedstawienie w Zurychu i że zrobiło na nim ogromne wrażenie: „Nie mogę wcale dużo powiedzieć o Umarłej klasie, ale mogę przywołać obrazy z niej. Widzę tych ludzi, jak wstają i siadają” (Marthaler 2007). Analogie między teatrem szwajcarskiego i polskiego reżysera wykraczają zresztą poza czysto zewnętrzne podobieństwa estetyczne czy postdramatyczność i dotyczą także takich kwestii, jak polityczność czy pamięć. Równocześnie inscenizatorski charakter pisma Marthalera jest tak skrajnie osobisty, oryginalny i indywidualny, że jego spektakle można rozpoznać, patrząc na zdjęcia czy słuchając fragmentów ścieżek dźwiękowych. I pozostaje jednym z najtrudniejszych do naśladowania. Nawet jeśli reżyser bierze na warsztat mniej (Faust Fernanda Pessoi i obie części Fausta Johanna Wolfganga Goethego, W Alpach Elfriede Jelinek) lub bardziej konwencjonalne formalnie teksty dramatyczne (Trzy siostry Antona Czechowa, Aferę na ulicy Lourcine Georges'a Feydeau, Burzę i Wieczór Trzech Króli Williama Szekspira, Śmierć Dantona Georga Büchnera, Kazimierza i Karolinę, Opowieści lasku wiedeńskiego oraz Wiarę, nadzieję, mitość Ödöna von Horvátha, Wesele Eliasa Canettiego) - dramatyczne, a nie prozatorskie (takie jak Kopista Bartleby Hermanna Melville’a, utwory Maurice’a Maeterlincka, Antonia Machado czy Ingeborg Bachmann) - akcja dramatyczna zostaje sprowadzona niemal do zera. Zamiast Freytagowskiego trójkąta - anemicznie wznosząca się i opadająca, długa i rozmazana linia falista. 
Teatralna formuła zostaje zdekomponowana, hierarchia elementów zachwiana. Po pozbyciu się agonu, rozpoznania, katastrofy pozostają swoiste dramatyczne odpadki, ścinki, normalnie pełniące funkcje wypełniacza czy spoiwa: odpoczywanie, wysiadywanie przy stole, przebieranie się, nieposuwający akcji do przodu small talk. Reżysera interesują bezruch, czekanie, sen, powolny rozpad, starzenie się, milczenie, apatia, niemoc, bezradność, tęsknota, nostalgia, depresja, demencja, otępienie, błędne koło powtarzalnych gestów bez znaczenia. Jednak brak aktywności wcale niekoniecznie musi oznaczać słabość, konformizm czy przegraną. Emblematycznym bohaterem teatru Marthalera jest Melville'owski Bartleby, który w spektaklu Lieber nicht. Eine Ausdünnung (Volksbühne, 2003) powtarzał tytułowe „Wolałbym nie”, stawiając bierny opór popadającemu w coraz większe szaleństwo światu.

W teatrze Marthalera podstawowym pojęciem jest rytm. Rytm muzycznego akompaniamentu, słów, śpiewu, gestów, złożonej z prostych, „codziennych”, obsesyjnie powtarzanych elementów choreografii. Jego spektakle mają charakter polifoniczny, nielinearny, a języki i znaki w nich używane są ze sobą łączone na takiej zasadzie, na jakiej komponuje się elementy struktury muzycznej. Ich logika to nie logika tekstu, Arystotelesowskiej tragedii z narastającą i opadająca krzywą fabuły, ale logika kompozycji, gdzie napięcia nie mają nic wspólnego z tzw. sensem życiowym. Słowo nie zajmuje już uprzywilejowanej pozycji, jaką zajmowało w logocentrycznej tradycji teatru dramatycznego; z drugiej strony jednak, zostaje mu przywrócona cała paleta barw często niedostrzeganych i zblakłych: rytm, intonacja, melodia, miękkość samogłosek, twardość spółgłosek, śpiewność wydłużonych sylab stają się elementami spektaklu nie mniej ważnymi niż barwa światła czy kształt dekoracji.

\section{Muzyka/muzyczność}

Teatr Marthalera jest teatrem z ducha muzyki w ścisłym tego określenia znaczeniu. Artysta urodził się w 1951 roku w szwajcarskiej miejscowości Erlenbach. W Zurychu odbył studia muzyczne (gra na flecie prostym i oboju), których dopełnieniem był kurs pantomimy u Jacques’a Lecoqa w Paryżu. W latach 70. rozpoczął wspólpracę jako muzyk teatralny i kompozytor z różnymi scenami obszaru niemieckojęzycznego (głównie Theater am Neumarkt w Zurychu $)^{1}$. Okazją do zbliżenia się do świata sztuk performatywnych były także projekty związane z muzyką współczesną: w 1980 roku w ramach zorganizowanej w Zurychu międzynarodowej wystawy pod tytułem Der Hang zum Gesamtkunstwerk (Dążenie do Gesamtkunstwerk) przygotował wieczór muzyki Erika Satiego na dwa fortepiany, śpiewaka i czworo aktorów; realizował projekty oparte o muzyczne idee Kurta Schwittersa i Johna Cage’a, a do Satiego wrócił w 1985 roku, przygotowując w ramach Minimal Festiwal w Zurychu dwudziestosześciogodzinne wykonanie Vexations.

Na przełomie lat 70. i 80. Marthaler współpracował z teatrami offowymi (z Dodo Hug i Pepe Solbachem założył grupę Tarot, aktywną w latach 1974-1979) i zaczął realizować

\footnotetext{
1 Jako ciekawostkę można przytoczyć fakt, że jedno z pierwszych profesjonalnych doświadczeń współpracy Marthalera z teatrem również zostało podjęte za pośrednictwem polskiego artysty: Szwajcar wystąpił bowiem jako jeden z żydowskich muzykantów w inscenizacji Zmierzchu Izaaka Babla w reżyserii Jerzego Jarockiego w Schauspielhaus w Zurychu w 1984 roku.
} 
w teatrach szwajcarskich małe projekty teatralne: wieczorki pieśni i piosenek tradycyjnych, ludowych, patriotycznych, popularnych, kabaretowych, operetkowych i operowych, połączonych przewodnim motywem tematycznym. Międzynarodowy rozgłos przyniosą mu tego typu projekty realizowane w teatrze w Bazylei, dokąd w 1989 roku sprowadził go dyrektor Frank Baumbauer i gdzie Marthaler poznał swoje stałe współpracowniczki: scenografkę Annę Viebrock i dramaturżkę Stefanie Carp.

Skandalem skończyły się premiery pierwszych autorskich spektakli realizowanych w Bazylei: Soldatenliederabend (Wieczorek pieśni żotnierskich) i Wenn das Alpenhirn sich rötet, tötet, freie Schweizer, tötet (Gdy mózg alpejski się czerwieni, zabijajcie, wolni Szwajcarzy, zabijajcie $)^{2}$ z 1989 roku oraz Stägeli uf, Stägeli ab, juhee! z 1990 roku. Spektakle te były sygnałem przejścia Marthalera z pozycji neodadaisty na pozycję artysty zaangażowanego politycznie, reagującego na zmieniającą się rzeczywistość (premiera Soldatenliederabend zbiegła się z referendum dotyczącym armii), co poskutkowało nie tylko podążeniem za Baumbauerem do Hamburga, ale też rychłym zaproszeniem przez Franka Castorfa do berlińskiej Volksbühne. Patetyczno-bogoojczyźniane lub sielankowo-kiczowate pieśni opiewające Szwajcarię jako ojczyznę ludzi wolnych i miłujących wolność innych, szlachetnych i walecznych, to znów jako krainę mlekiem, miodem i czekoladą płynącą, brzmiały ironicznie, groteskowo, przerażająco w kontekście wciąż wypieranej historycznej prawdy o przeszłości kraju. Marthaler nie musiał opatrywać śpiewanych przez aktorów utworów komentarzem: widzom wystarczyła świadomość, że niedaleko bazylejskiego teatru znajduje się dworzec, z którego podczas II wojny światowej deportowano do Niemiec Żydów.

W 1994 roku Marthaler zaczął realizować projekty operowe (we Frankfurcie, w Berlinie, Bayreuth, Wiedniu i Salzburgu), sięgając głównie po opery „literackie”, takie jak Peleas i Melisanda Claude’a Debussy'ego z librettem według Maurice’a Maeterlincka (Opera Frankfurcka, 1994), Traviata Giuseppe Verdiego (Opéra national de Paris, 2007) czy utwory Richarda Wagnera (Tristan i Izolda w Festspielhaus w Bayreuth, 2005). Może to świadczyć o chęci zbliżenia do siebie teatru dramatycznego i operowego, odrzucenia sztucznych podziałów, ale też po prostu o poszukiwaniu takich dzieł, które dadzą artyście możliwość wykazania się sceniczną inwencją.

Dramaturżka Stefanie Carp tłumaczy, że Marthaler pracuje w teatrze w sposób podobny do kompozytora:

Forma jego spektakli jest zawsze specyficzną kompozycją. Obojętnie, czy reżyseruje dramat, czy kolaż różnych tekstów i muzyki, dopasowuje do określonego tematu muzycznego swój materiał językowy, gestyczny, działania, muzykę, procedury. Przekształca ten materiał w partyturę rytmiczną i muzyczną, która akompaniuje całego spektaklowi jako rodzaj podtekstu. Ta partytura często $\mathrm{w}$ większym stopniu niż tekst tematyzuje daremną tęsknotę postaci (Carp 1997: 66).

W postdramatycznym teatrze Marthalera to muzyka i rytm, nie zaś dramat i akcja są gwarantami spójności inscenizacji (Roesner 2003; Lehmann 2004; Roesner 2014). Potencjał akcji w sensie fabularnym, anegdotycznym wyczerpuje się bardzo szybko, te-

2 Tytuł jest parafrazą fragmentu hymnu narodowego Szwajcarski Psalm autorstwa Leonharda Widmera: "Wenn der Alpen Firn sich rötet, betet, freie Schweizer, betet" („Gdy śnieg alpejski się czerwieni, módlcie się, wolni Szwajcarzy, módlcie się"). 
matykę większości z autorskich przedstawień reżysera można streścić w jednym zdaniu. Na przykład Muszka owocowa (Die Fruchfliege, Volksbühne, 2005) to opowieść o tym, jak $\mathrm{w}$ pewnym laboratorium zaludnionym przez podstarzałych naukowców w poszarzałych kitlach i okularach o grubych szkłach wydostała się z probówek substancja wywołująca zakochanie, co spowodowało, że nieśmiali, niezgrabni, zaniedbani dziwacy zaczęli się mieć ku sobie, co wyrażają śpiewem, czerpiąc z repertuaru arii i pieśni miłosnych od Mozarta, Pucciniego, Verdiego i Wagnera, przez Friedricha Holländera aż po (jadowicie sparodiowanego) Andrew Lloyda Webbera. Każde z tych wykonań jest w zasadzie mikrospektaklem, etiudą nie tylko wokalną, lecz także aktorską w pełnym tego słowa znaczeniu. Etiudy te nie poruszają akcji do przodu, ale odsłaniają przed widzami najrozmaitsze warianty naczelnego tematu spektaklu - od beztroskiego flirtu po miłosną tragedię.

Większość spektakli Marthalera można opisać, porównując je do formy muzycznej wariacji. Obrany temat (lub jego motywy) podlega zmianom i pojawia się w kilkunastu (lub więcej) wariacjach. Wprowadzane zmiany mają różny charakter: zmieniają się melodyka, metrum, dynamika, tempo, forma (mono- lub polifoniczna), ale też nastrój, konwencja estetyczna, wymowa. Konstytutywne dla przedstawienia napięcie rodzi się między powtórzeniem a różnicą.

Równocześnie spektakle te bardzo dużo zawdzięczają tradycji kabaretu i rewii, z ich dramaturgią pojedynczych numerów, luźno połączonych ze sobą nadrzędnym tematem czy ideą. Poszczególne numery mogą być solowe, w duecie, trio, kwartecie, chóralne; mogą mieć charakter popisu wokalnego (lub wokalno-muzycznego), werbalnego czy też choreograficznego. Zamiast jednego punktu kulminacyjnego, publiczność otrzymuje ich kilkanaście lub kilkadziesiąt.

\section{Aktorzy}

Reżyser od dekad pracuje z tym samym zespołem (Olivia Grigolli, Bettina Stucky, André Jung, Ueli Jäggi, Josef Ostendorf, Jean-Pierre Cornu, Graham F. Valentine). Co istotne, nie tylko przy okazji festiwalowych koprodukcji, ale też przygotowując premiery w teatrach repertuarowych, mających swoje własne, stałe zespoły aktorskie. To z reguły albo wyjątkowo uzdolnieni wokalnie aktorzy dramatyczni, albo wyjątkowo otwarci na nietypowe wyzwania aktorskie śpiewacy operowi. Na scenie granice między tymi dwoma grupami profesjonalistów zacierają się.

Teatralny świat Marthalera zaludniają wedle jego monografisty, Klausa Dermutza, ludzie „powolni i specjalni” (Dermutz 2000). Fascynuje go szczególny typ powierzchowności i ekspresji, budzący współczucie i rozbawienie zarazem - aktorzy dobierani są tak, by nie trzeba było ich zbyt mocno charakteryzować. Na wspólne sceniczne trwanie są skazani bohaterowie poniżej przeciętności: podstarzali, nieatrakcyjni, niezgrabni, cherlawi lub skrajnie otyli, nudni, niezbyt mądrzy, niezbyt schludni, zaniedbani, biedni. Ulubioną figurą tego teatru jest ubrany w niemodny uniform urzędnik najniższej rangi: ktoś zawieszony między dumą z posiadanego wykształcenia i wstydem z powodu swojego ubóstwa, dumny z władzy nad petentami a zarazem pogardzany jako najniższe ogniwo w biurokratycznej maszynie. Rachityczna roślina wyhodowana w ciemnym biurze czy urzędzie, blade odbicie miesz- 
czańskich ideałów, pokraczne twory masowej kapitalistycznej produkcji, zakompleksieni dziwacy, dla których łatwiejszy, bardziej nasycony emocjami jest kontakt z przedmiotami niż z drugim człowiekiem.

W wypadku tego teatru trudno właściwie mówić o postaciach w tradycyjnym tego słowa znaczeniu - często wykonawcy występują na scenie pod własnymi imionami i obdarzają swoje figury własnymi cechami charakteru i biografiami. Symptomatyczna dla metod pracy Marthalera z aktorami może być anegdota dotycząca spektaklu Riesenbutzbach. Stała kolonia (Wiener Festwochen, 2009). Po jego pokazach w ramach wrocławskiego festiwalu „Dialog” w październiku 2009 roku jeden z widzów zadał pytanie Stefanie Carp, czy niemożliwe duety śpiewającego po francusku syna i śpiewającej po niemiecku matki (każde ich spotkanie kwitującej słowami „Mój syn. Francuz. Nie rozumiem go od urodzenia”) są metaforą trudnych relacji Francji i Niemiec w Unii Europejskiej. Dramaturżkę rozbawiła ta interpretacja - wytłumaczyła, że francuski śpiewak grający syna nijak nie potrafił nauczyć się niemieckiego, więc jako jedyny w obsadzie śpiewa i mówi po francusku.

W Riesenbutzbach. Stałej kolonii mikrofony w ścianach i meblach nagłaśniały każde dotknięcie, ruch, krok. Aktorzy nie tylko śpiewali, ale ich ciała stanowiły czułe struny rozpięte $\mathrm{w}$ pudle rezonansowym sceny. $\mathrm{W}$ tym i w innych spektaklach muzycznej warstwie wtórowała choreografia balansująca na granicy normalnego, codziennego, „brzydkiego” ruchu i tańca nowoczesnego w duchu teatru tańca Piny Bausch. Bohaterowie spektakli Marthalera wydają się mieć nieustający problem z utrzymaniem równowagi, balansują pokracznie między elementami scenografii a widownią.

Marthalera fascynuje zderzenie słabego, fajtłapowatego, bezkształtnego ludzkiego ciała z systemem kontroli i porządku. Skupienie na tym napięciu, eksponowanie mechanizacji ruchu, rytmu, powolności czasu daje efekt humorystyczny (Bergson 2000), a w zasadzie slapstickowy. Slapstick oznacza degradację bohatera, dekonstrukcję jego mitu, uczynienie go bezwolną marionetką miotaną na wszystkie strony przez bezosobowe, zmechanizowane siły losu. Z prób przezwyciężania słabości rodzi się komizm, ale też piękno tego teatru. Pokraczni, nieśmiali, przygaszeni, gdy mówią, chodzą, pracują, bohaterowie rozkwitają, gdy zaczynają śpiewać.

W taki właśnie sposób funkcjonuje muzyka w Murxie. Wszystkie wykorzystane w spektaklu utwory, przy różnicach stylu, rytmu, tonacji, łączy bardzo silnie to, że pochodzą z momentów przełomu w historii Niemiec. Sichres Deutschland, schläfst du noch? z muzyką Michaela Jacobiego i tekstem Johanna Rista to utwór powstały po podpisaniu kończącego wojnę trzydziestoletnią pokoju westfalskiego; Flamme empor skomponowane przez Karla Gläsera do tekstu Christiana Nonnego pochodzi z czasów narastania dążeń zjednoczeniowo-narodowych na przełomie XVIII i XIX wieku, podobnie jak Das Lied der Deutschen Josepha Haydna z tekstem Augusta Heinricha Hoffmanna von Fallersleben (od 1992 roku z przerwami hymn niemiecki). Wszystkie te utwory - akcentujące dumę z bycia Niemcami i przekonanie o wyjątkowej roli przeznaczonej do odegrania w świecie Germanom - wykorzystywała propaganda narodowosocjalistyczna. Wraz z takimi kompozycjami jak Unsre Fahne flattert uns voran (pieśń Hitlerjugend) czy hymn DDR Hannsa Eislera i Johannesa T. Bechera z jednej strony, a kabaretowy przebój z czasów schyłku Republiki Weimarskiej Ich laß mir meinen Körper schwarz bepinseln Friedricha Hollaendra i Roberta Liebmanna z drugiej, „playlista” Murxa układa się w kształt makabryczno-groteskowego, patetycznie-komicznego muzycznego drzewa genealogicznego współczesnych Niemiec. 


\section{Scenografia}

Prawą ręką Marthalera od lat jest scenografka Anna Viebrock. Piszący o jej projektach Sergio Morabito (Morabito 2000) określił tworzone przez nią przestrzenie jako „Wahnzimmer”, co jest grą słów: połączeniem niemieckiego „Wohnzimmer” (pokój mieszkalny) z „Wahn” (obłęd). Viebrock odtwarza na scenie odwiedzone osobiście lub zobaczone na fotografiach opustoszałe przestrzenie, w których czas się zatrzymał, a wszelkie życie zamarło: smętne opuszczone dworce, ponure zrujnowane szpitale, melancholijne nieczynne hotele i restauracje, w których wciąż zachowały się żałosne ślady dawnego luksusu i niedzisiejszej elegancji. Jest to swoista estetyka resztek; śladów pamięci, które wiążą przeszłość z teraźniejszością.

Marthalera i Viebrock fascynują te miejsca, gdzie publiczne staje się prywatne, a prywatne - publiczne. Ale też te, gdzie historia i teraźniejszość zderzają się ze sobą, gdzie, jak pisał Pierre Nora, „krystalizuje się i wydziela pamięć” (Nora 2001). Prawdy historycznej nie da się odtworzyć; można tylko odtworzyć emocjonalne związki z nią i własną konieczność pamiętania. Duet artystów od samego początku swojej działalności mierzy się z historią i domaga się pamięci o tych, których istnienie wymazano z powszechnej świadomości. Być może najważniejszym obok Murxa projektem Christopha Marthalera i Anny Viebrock jest zrealizowany w ramach Wiener Festwochen spektakl Schutz vor der Zukunft (Ochrona przed przyszłościa , 2005). Przed rozpoczęciem przedstawienia widzowie zwiedzali wystawę urządzoną na terenie szpitala psychiatrycznego Am Steinhof - miejsca, w którym dokonano eugenicznego mordu na wielu setkach chorych psychicznie dzieci ${ }^{3}$. Puste lóżka, pocztówki na słomiankach i drewniane zabawki wykonane rękami pacjentów przemawiają zupełnie innym głosem, gdy zestawiło się je z odtwarzanymi suchymi relacjami opisującymi poszczególne przypadki chorobowe: historie dzieci uznanych za „niepełnowartościowe”, wykorzystywanych do pseudonaukowych eksperymentów, w końcu uśmiercanych.

Po tym wstępie widzowie przechodzili do starej świetlicy, gdzie czekały na nich długie, pokryte obrusami stoły, na których wciąż jeszcze stały filiżanki niedopitej kawy i leżały sterty porozrzucanego konfetti, a pod ścianami stały ulepione z chleba modele budynków Steinhofu i niezliczone słoiki z galaretowatą substancją przypominająca ludzki mózg. Wreszcie pojawiali się celebransi tego wieczoru - karykaturalne postaci znane z poprzednich spektakli Marthalera: ociężałe, pokraczne, w niemodnych strojach, groteskowych fryzurach, grubych okularach; dziecinne i niezdarne. Wyglądające tak, jakby nigdy nie osiągnęły pełni rozwoju fizycznego i psychicznego, tylko z dzieciństwa przeszli od razu w stan starczego uwiądu. Te dziwaczne postaci wygłaszały upiorny wykład o eugenice, a następnie zapraszały na koncert, „by zagrać na pożegnanie naszym maluchom z bogatego w tradycje Szpitala Ottona Wagnera”. Przy wtórze kołysanek i pieśni z romantycznego „śpiewnika domowego”, pieśni Smutek Roberta Schumanna, preludiów i fug Szostakowicza, Pieśni o dziecięcej śmierci Gustava Mahlera, przeplatana mowami o zapewnieniu rasie ludzkiej świetlanej przyszłości, toczyła się (tyleż groteskowo strywializowana, co w pełni uprawomocniona

3 Z przyczyn technicznych spektaklu w zasadzie nie pokazywano poza Wiedniem i miejscem, które go zainspirowało. Wyjątkiem był pokaz w ramach festiwalu "Dialog” we Wrocławiu (2005) - odbył się w nie mniej efektownym architektonicznie szpitalu psychiatrycznym w Lubiążu, którego mury również przechowują pamięć zbrodni dokonywanych rzekomo w imię nauki. 
tragicznym kontekstem) trawestacja Ostatniej Wieczerzy, a zarazem osobliwy koncert życzeń, podczas którego dzieci były oddawane w ręce „aniołów śmierci”, okazujących się koszmarnymi klaunami rodem z nocnych lęków dzieciństwa.

W wypadku współpracy Marthalera i Viebrock często to właśnie konkretne miejsce, konkretna przestrzeń jest jednym z głównych punktów wyjścia do pracy nad spektaklem. Scenografka obsesyjnie kolekcjonuje zdjęcia miejsc, „w których czas się zatrzymał”, niszczejącej architektury, szkaradnych mebli, pokracznych przedmiotów, niegustownych strojów. Wraz z reżyserem symbolicznie zasiedlają je - nie tyle ludźmi, co muzyką. Bardzo szczególna forma teatralnego rytuału przeciwko śmierci. Ulotna i trudna do naśladowania.

\section{Kamień milowy}

Teatr Christopha Marthalera to wzorcowy przykład teatru postdramatycznego - spektakle Szwajcara można oglądać z książką Hansa-Thiesa Lehmanna w ręku, odkreślając po kolei punkty podsumowujące cechy szczególne tej odmiany sztuki: odejście od syntetyzującej funkcji dramatu i hierarchicznego uporządkowania poszczególnych komponentów przedstawienia; dowartościowanie scenografii, rekwizytu, kostiumu, światła, dźwięku, rytmu, ciała jako równoprawnych środków wyrazu; śmierć postaci dramatycznej w tradycyjnym tego słowa znaczeniu; odejście od wymogu spójności i logiczności akcji; fragmentaryczność, zdarzeniowość, symultaniczność i różnorodność znaków scenicznych; nowy model relacji z widzem, odległy zarówno od dramatycznego „wczucia”, jak i epickiej emancypacji. Jedynie z mediami reżyserowi Murxa... nie jest po drodze, trudno w jego teatrze szukać kamer i ekranów, choć inspiracje kinowe są w nim jak najbardziej obecne (zwłaszcza tradycja anarchistycznej komedii slapstickowej). Jego styl jest bardzo wyrazisty, konsekwentnie rozwijany we wszystkich kolejnych produkcjach - wystarczy zobaczyć fragment jednego spektaklu Szwajcara, by być w stanie już zawsze rozpoznać jego autorstwo.

Nie jest to jednak zjawisko artystyczne marginalne czy niszowe. Dzięki temu, że Marthaler bardzo szybko zaczął pracować w profesjonalnych, państwowych teatrach (w tym najważniejszych scenach Europy - berlińskiej Volksbühne, hamburskim Deutsches Schauspielhaus, zuryskim Schauspielhaus) oraz pokazywać swoje produkcje na międzynarodowych festiwalach, jego estetyka, tematyka, jaką porusza, i metoda pracy bardzo szybko przeniknęly z artystyczno-organizacyjnego offu, „szarej strefy” między teatrem, koncertem a polityczną demonstracją, do głównego nurtu współczesnego teatru. „Zjawisko Marthaler", choć tak osobne i - nazwijmy to wprost - ekscentryczne, zaczęło więc wpływać na inne zjawiska i nasiąkać obcymi wpływami (np. w zakresie aktorstwa - tacy wykonawcy, jak Martin Wuttke czy Sophie Rois, których ekspresja ukształtowała się głównie we współpracy z Frankiem Castorfem, wnieśli do teatru Marthalera zupełnie nową jakość).

Opisany przeze mnie na początku artykułu Murx... to inscenizacja ważna także z polskiego punktu widzenia, ponieważ zmieniła nieodwracalnie (a zmianę tę umocniły kolejne, bez wyjątku entuzjastycznie przyjęte spektakle Szwajcara prezentowane nad Wisłą 
i Odrą) $)^{4}$ myślenie krajowych artystów, kuratorów, badaczy, krytyków, widzów o teatrze: o jego języku, regułach konstrukcyjnych, wewnętrznej hierarchii, roli, oddziaływaniu na widza. Nie tylko pozwoliła zdiagnozować stan polskiego teatru w czasie dynamicznych przemian polityczno-organizacyjno-estetycznych i wyznaczyła trendy na przyszłość, ale też przewartościowała przeszłość (ze znajomością dokonań Marthalera inaczej patrzy się chociażby na dorobek inspirującego go Tadeusza Kantora czy zaskakująco bliskiemu mu formalnie, zwłaszcza $\mathrm{w}$ swoich operetkowo-wodewilowych przedstawieniach, Jerzego Grzegorzewskiego).

$\mathrm{Na}$ inspirację teatrem Marthalera powołuje się bardzo wielu reżyserów, choreografów i aktorów pokolenia, które pojawiło się w polskim teatrze w XXI wieku, m.in. Jan Klata (Klata 2010), Barbara Wysocka (Wysocka 2010b), Maja Kleczewska (Didaskalia 2005) (od lat planująca współpracę z Anną Viebrock), Piotr Kruszczyński (Didaskalia 2005), Wojtek Klemm (Klemm 2014), Maćko Prusak (Prusak 2010), Marcin Czarnik. Jego wyraźne wpływy widać też chociażby w twórczości Cezarego Tomaszewskiego (np. Cezary idzie na wojnę, gdzie poczciwe pieśni Moniuszki służą dekonstrukcji narodowych mitów, obowiązującego w Polsce modelu męskości, kultu militaryzmu) i Magdy Szpecht (głównie w melancholijnej inscenizacji Schubert. Romantyczna kompozycja na dwunastu wykonawców $i$ kwartet smyczkowy). Czasami te ślady są bardzo dosłowne, łatwo uchwytne, pojawiające się nieomal na prawach cytatu: pół prywatna, pół aktorska obecność instrumentalistów na scenie, niezgrabnie poruszający się aktorzy w niemodnych, brzydkich swetrach i „babcinych" oprawkach okularów o grubych szkłach, retro fotele obite brunatnym skajem. Ale inspiracje i podobieństwa mogą sięgać o wiele głębiej. Mogą się wyrażać w docenieniu muzyki jako nośnika pamięci i (nie zawsze szlachetnych) zbiorowych emocji, nieufnym podejściu do słowa, przyznaniu muzykom i aktorom statusu raczej performerów, niż odtwórców-wykonawców, skupieniu na choreografii codzienności, odejściu od dramatycznej struktury inscenizacji w kierunku struktury muzycznej, wreszcie na bardzo szczególnej dehierarchizacji teatru, rozumianej zarówno jako dehierarchizacja elementów składających się na spektakl (szuranie kapciami może być równie ważne, co mistrzowsko napisany monolog), jak i jako dehierarchizacja członków zespołu pracujących nad spektaklem (pracownicy techniczni sceny są nie mniej ważni niż aktorzy). Teatr Marthalera wciela to, co Heiner Müller (a za nim Heiner Goebbels, w swoich muzyczno-teatralnych poszukiwaniach pod wieloma względami bliski szwajcarskiemu artyście) opisał jako „quasi-demokratyczny”, „anty-dyktatorski teatr" (Goebbels 2015) - udział w nim (zarówno w roli twórcy, jak i widza) uczy doceniać najważniejsze reguły społeczne i ich przestrzegać. Postdramatyczność to nie tylko modny styl - postdramatyczność wysuwa ważne żądania etyczne (nie tylko wtedy, gdy dotyka kwestii politycznych konfliktów czy rozlicza historię). Być może to jest najważniejsza nauka, jaką możemy wynieść z teatru Christopha Marthalera.

\footnotetext{
${ }_{4}$ Pełna lista prezentacji spektakli Christopha Marthalera w Polsce: 1996 - Murx den Europäer! (Międzynarodowy Festiwal Teatralny „,Kontakt” w Toruniu); 2001 - Specjaliści (Międzynarodowy Festiwal Teatralny Dialog - Wrocław); 2005 - Ostrzeżenie przed przyszłościq (Międzynarodowy Festiwal Teatralny Dialog - Wrocław); 2005 - Podróż Liny Bögli (Festiwal baz@rt w Krakowie); 2009 - Muszka owocówka (dwukrotnie: Przegląd Piosenki Aktorskiej we Wrocławiu i Międzynarodowy Festiwal Teatralny „Kontakt”); 2009 - Riesenbutzbach. Stała kolonia (Międzynarodowy Festiwal Teatralny Dialog - Wrocław); 2012 - +-0. Baza podbiegunowa (festiwal Warszawa Centralna). Ponadto w 2005 roku Marthaler wyreżyserował Sprawę Makropulos Leoša Janáčka w Teatrze WielkimOperze Narodowej w Warszawie.
} 


\section{Bibliografia}

Bergson, Henri 2000. Śmiech. Esej o komizmie. Tłum. Stanisław Cichowicz. Warszawa: KR.

Carp, Stefanie 1997. „Langsames Leben ist lang. Zum Theater von Christoph Marthaler”. Theaterschrift 12.

Dermutz, Klaus 2000. Christoph Marthaler. Die einsamem Menschen sind die besonderen Menschen. Salzburg: Residenz.

Goebbels, Heiner 2015. Przeciw Gesamtkunstwerk. Tłum. Anna R. Burzyńska, Sławomir Wojciechowski. Kraków: Korporacja HA!ART.

Klata, Jan 2010. „Druga strona singla. Z Janem Klatą rozmawia Anna R. Burzyńska”. Didaskalia 97-98.

Klemm, Wojciech 2014. „Wszystko jest polityczne. Z Wojtkiem Klemmem rozmawia Mike Urbaniak”. https://mikeurbaniak.wordpress.com/2014/10/21/wszystko-jest-polityczne/ [20.03.2018].

Lehmann, Hans-Thies 2004. Teatr postdramatyczny. Tłum. Małgorzata Sugiera, Dorota Sajewska. Kraków: Wydawnictwo Księgarnia Akademicka.

Marthaler, Christoph 2007. „Kantor - inicjacja”. W: Uta Schorlemmer (red.). Sztuka jest przestępstwem. Tadeusz Kantor a Niemcy i Szwajcaria. Kraków: Cricoteka i Verlag für moderne Kunst Nürnberg.

Morabito, Sergio 2000. „Wahnzimmer”. W: Bettina Masuch (red.). Anna Viebrock. Bühnen/Räume. Damit die Zeit nicht stehenbleibt. Berlin: Theater der Zeit.

Nora, Pierre 2001. „Między pamięcią a historią/Les lieux de memoire”. Didaskalia 105.

Prusak, Maciej 2010. „Wina nigdy nie leży po stronie muzyki. Z Maćkiem Prusakiem rozmawia Anna R. Burzyńska”. Didaskalia 97-98.

Roesner, David 2003. Theater als Musik. Verfahren der Musikalisierung in chorischen Inszenierungen bei Christoph Marthaler, Einar Schleef und Robert Wilson. Tübingen: Gunter Narr.

- 2014. Musicality in Theatre. Music as Model, Method and Metaphor in Theatre-Making. Farnham: Ashgate.

„Sonda. Maja Kleczewska, Piotr Kruszczyński, Małgorzata Sugiera [Ostrzeżenie przed przyszłością]” 2005. Didaskalia 70.

Wysocka, Barbara 2010a. „Dziwny twór. Aktor-reżyser. Pola Sobaś-Mikołajczyk rozmawia z Barbarą Wysocką”. Ultramaryna 3. http://www.ultramaryna.pl/tekst.php?id=811 [20.03.2018].

— 2010b. „Reaktor w stanie nadkrytycznym. Rozmowa z Barbarą Wysocką. Agata DiduszkoZyglewska”. Dwutygodnik 01. http://www.dwutygodnik.com/artykul/820-reaktor-wstanie-nadkrytycznym.html [20.03.2018]. 